\title{
PENINGKATAN KEMAMPUAN MOTORIK HALUS ANAK MELALUI KEGIATAN MONTASE USIA 5-6 TAHUN DI TK BARUNAWATI 3 SAMARINDA
}

\author{
IMPROVING FINE MOTOR ABILITY THROUGH MONTAGE ACTIVITY OF \\ CHILDREN AGE 5-6 YEARS IN BARUNAWATI 3 SAMARINDA
}

Setia Anggawati, Sujiman, Fachrul Rozie

Universitas Mulaw arman

fachrulroziepgpaud@gmail.com

\begin{abstract}
Abstrak
Berdasarkan hasil pengamatan di lapangan terhadap kemampuan motorik halus anak di TK. Barunawati 3 Samarinda masih rendah. Penilitian ini merupakan penelitian tindakan kelas (classroom action research) yang bertujuan untuk mengembangkan kemamuan motorik halus anak dengan kegiatan montase. Penelitian dilakukan sebanyak tiga siklus, setiap siklus terdiri dari tahap perencanaan, tindakan, observasi dan refleksi. Hasil penelitian pada siklus I, II, dan III menunjukan bahwa terdapat peningkatan kemampuan motorik halus anak setelah pemberian kegiatan montase. di TK. Hasil penelitian yang dilakukan menunjukkan perolehan jumlah nilai pada siklus I yaitu 151 perolehan nilai rata-rata yaitu 38\%. Pada siklus II yaitu $246 \%$ perolehan nilai rata-rata yaitu $61,5 \%$. Pada siklus III yaitu 350,5\% nilai rata-rata yaitu $88 \%$ dengan kriteria berkembang sangat baik. Berdasarkan data tersebut, dapat disimpulkan kegiatan montase dapat meningkatan kemampuan motorik halus anak usia 5-6 tahun di TK. Barunawati 3 samarinda.
\end{abstract}

Kata kunci: Kemampuan Motorik Halus, Kegiatan Montase.

\begin{abstract}
Based on the results of field observations on the fine motor skills of children in TK. Barunawati 3 Samarinda is still low. This research is $=$ a classroom action research which aims to develop children's fine motor skills through montage activities. The research was conducted in three cycles, each cycle consisting of planning, action, observation and reflection stages. The results of the research in cycles I, II, and III showed that there was an increase in the child's fine motor skills after giving montage activities. in kindergarten. The results of the research conducted showed that the acquisition of the total value in the first cycle was 151 mean value acquisition, namely $38 \%$. In the second cycle, namely $246 \%$, the average value was $61,5 \%$. In cycle III, namely $350.5 \%$, the average value is $88 \%$ with very well developed criteria. Based on the data above, it can be concluded that montage activities can improve the fine motor skills of children aged 5-6 years in TK. Barunawati 3 samarinda. Keyword: fine motor skill, montage activity
\end{abstract}




\section{PENDAHULUAN}

Undang-undang Sistem Pendidikan Nasional No. 20 Tahun 2003 Pasal 1 ayat (14) menjelaskan bahwa pendidikan anak usia dini adalah suatu upaya pembinaan yang ditujukan kepada anak sejak lahir sampai dengan usia 6 tahun yang dilakukan melalui pemberian rangsangan untuk membantu pertumbuhan dan perkembangan jasmani dan rohani agar anak memiliki kesiapan dalam memasuki pendidikan lebih lanjut. Pendidikan anak usia dini merupakan pondasi dasar pendidikan yang diberikan kepada anak-anak usia 0-6 tahun sebagai suatu usaha untuk mengembangkan berbagai aspek perkembangan anak dengan mengoptimalkan stimulasi yang diberikan sejak dini.

Dalam perkembangan anak usia dini terdapat 6 aspek perkembangan, salah satu aspek yang penting untuk dikembangkan di dalam Pendidikan Anak Usia Dini adalah aspek perkembangan motorik kasar dan motorik halus. Motorik kasar merupakan gerakan yang menggunakan otot-otot besar seperti berjalan, melompat, menendang, berlari, dan sebagainya sedangkan motorik halus dapat diartikan sebagai suatu keterampilan yang membutuhkan kontrol yang kuat terhadap otot khususnya yang termasuk keterampilan pergerakan jarijemari tangan, koordinasi mata dan tangan, serta keterampilan yang membutuhkan keterampilan pergelangan tangan seperti menggunting, menjahit, menulis, menggambar, mewarnai, dan sebagainya. Pada usia 5-6 tahun merupakan usia diamana perkembangan motorik anak sangat aktif dalam berbagai kegiatan sehingga jika perkembangan motorik anak tidak dikembangkan dengan baik, akan berpengaruh pada perkembangannya kelak, terutama dalam perkembangan motorik halus anak.

Perkembangan motorik halus anak dapat dikembangkan dengan berbagai macam stimulasi, salah satunya dengan memberikan kegiatan montase. Montase merupakan sebuah karya yang dibuat dengan cara memotong objek-objek gambar dari berbagai sumber kemudian ditempelkan pada suatu bidang sehingga menjadi satu kesatuan karya dan tema (Muharrar dkk 2013:44) dan kegiatan montase sendiri merupakan penggabungan dari berbagai sumber, baik media cetak ataupun media gambar yang kemudian ditempelkan satu persatu dengan susunan dan penataan yang diinginkan sehingga menjadi sebuah karya seni baru yang disebut karya seni montase.

Berdasarkan pengamatan yang dilakukan peneliti pada anak usia 5-6 tahun di TK. Barunawati 3 Samarinda menunjukkan bahwa kemampuan motorik halus anak di TK tersebut masih belum berkembang. Keterampilan motorik halus yang masih rendah diantaranya; (1) memegang benda/alat dengan baik (antara ibu jari dan 2 jari); (2) menempel gambar dengan 
tepat; (3) menggunting sesuai pola garis vertikal, horizontal, lengkung, lingkaran; (4) terampil menggunakan jari tangan, (mewarnai, menggambar) dengan gerakan naik, turun, bersambung sehingga peneliti mengambil kekurangan tersebut sebagai aspek yang akan dinilai untuk ditingkatkan motorik halusnya. Dengan memberikan kegiatan montase ini guna untuk melatih keterampilan motorik halus anak dan juga mengenalkan kepada anak bahwa barang bekas seperti koran/majalah dapat berguna untuk digunakan kembali.

\section{METODE PENELITIAN}

Penelitian ini merupakan penelitian tindakan kelas (classroom action research) yang dalam perencanaan penelitiannya menggunakan metode penelitian tindakan model Kemmis dan Taggart dengan dibagi kedalam tiga siklus, dimana setiap siklus mempunyai langkahlangkah seperti : (1) perencanaan, (2) tindakan, (3) pengamatan, (4) Refleksi atau hasil observasi. Penelitian ini dilakukan di TK. Barunawati 3 Samarinda, dengan subjek penelitian anak usia 5-6 tahun yang berjumlah 10 anak (3 anak laki-laki dan 7 anak perempuan.)

\section{HASIL PENELITIAN DAN PEMBAHASAN}

Berdasarkan analisis data selama penelitian tindakan kelas yang dilaksanakan di TK. Barunawati 3 Samarinda berlangsung menunjukan bahwa kemampuan motorik halus anak kelompok B TK. Barunawati 3 Samarinda tahun 2016/2017 meningkat melalui kegiatan montase. Presentase nilai ketuntasan kemampuan yang diharapkan yaitu $70 \%$ pada setiapa indikator yang akan ditingkatkan. Penelitian dilakukan sebanyak tiga siklus, setiap siklus terdiri dari tahap perencanaan, tindakan, pengamatan dan refleksi.

Berdasarkan observasi dan analisis data yang telah dilaksanakan pada siklus I pertemuan 1 dan kedua masih banyak anak yang perlu diberi tindakan keterampilan motorik halusnya terutama dalam hal memegang alat dengan baik (antara ibu jari dan 2 jari) dan menggunting sesuai dengan pola garis vertikal, horizontal, lengkung, lingkaran. Berikut table observasi pada siklus I pertemuan 1:

\begin{tabular}{|c|c|c|c|c|c|c|}
\hline \multirow[t]{2}{*}{$\overline{\text { No }}$} & \multirow[t]{2}{*}{ Aspek yang dinilai } & \multicolumn{2}{|c|}{ Siklus I } & \multirow[t]{2}{*}{ Jumlah } & \multirow{2}{*}{$\begin{array}{l}\text { Rata- } \\
\text { rata }\end{array}$} & \multirow[t]{2}{*}{ Kriteria } \\
\hline & & $\mathrm{P} 1$ & $\mathrm{P} 2$ & & & \\
\hline 1 & $\begin{array}{l}\text { Memegang alat/benda dengan } \\
\text { baik (antara ibu jari dan } 2 \text { jari) }\end{array}$ & 30 & 35 & 65 & $32,5 \%$ & $\mathrm{BB}$ \\
\hline 2 & Menempel gambar dengan tepat & 40 & 50 & 90 & $45 \%$ & MB \\
\hline 3 & $\begin{array}{l}\text { Menggunting sesuai dengan pola } \\
\text { garis vertikal,horizontal, } \\
\text { lengkung, lingkaran }\end{array}$ & 28 & 33 & 61 & $30,5 \%$ & $\mathrm{BB}$ \\
\hline
\end{tabular}




\begin{tabular}{|c|c|c|c|c|c|c|}
\hline 4 & $\begin{array}{l}\text { Terampil menggunakan jari } \\
\text { tangan (mewarnai, } \\
\text { menggambar) dengan gerakan } \\
\text { naik, turun, bersambung. }\end{array}$ & 38 & 48 & 86 & $43 \%$ & $\mathrm{MB}$ \\
\hline \multicolumn{2}{|c|}{ Rata-rata } & & & & $38 \%$ & $\mathrm{BB}$ \\
\hline
\end{tabular}

Sumber: lembar observasi anak siklus I pertemuan ke-1 dan ke-2

Penelitian dilanjutkan dari siklus I ke siklus II. Setelah melakukan observasi pada siklus II pertemuan ke-1 dan pertemuan ke-2 memperoleh kenaikan presentase pada aspek memegang alat/benda dengan baik (antara ibu jari dan 2 jari) sebesar 26,5\%, menempel gambar dengan tepat sebesar 21,5\%, menggunting sesuai pola garis vertikal, horizontal, lengkung, lingkaran sebesar 27\%, terampil menggunakan jari tangan (mewarnai, menggambar) dengan gerakan naik, turun, bersambung sebesar 20\%. Setelah melakukan observasi pada pertemuan ke-1 dan pertemuan ke-2 dapat disimpulkan hasil rekapitulasi kemampuan motorik halus:

\begin{tabular}{|c|c|c|c|c|c|c|}
\hline \multirow{2}{*}{ No } & \multirow{2}{*}{ Aspek yang dinilai } & \multicolumn{2}{|c|}{ Siklus II } & \multirow{2}{*}{ Jumlah } & \multirow{2}{*}{$\begin{array}{l}\text { Rata- } \\
\text { Rata }\end{array}$} & \multirow{2}{*}{ Krite ria } \\
\hline & & $\mathrm{P} 1$ & $\mathrm{P} 2$ & & & \\
\hline 1 & $\begin{array}{l}\text { Memegang alat/benda } \\
\text { dengan baik (antara ibu jari } \\
\text { dan } 2 \text { jari) }\end{array}$ & 53 & 65 & 118 & $59 \%$ & MB \\
\hline 2 & $\begin{array}{l}\text { Menempel gambar dengan } \\
\text { tepat }\end{array}$ & 53 & 80 & 138 & $66,5 \%$ & BSH \\
\hline 3 & $\begin{array}{l}\text { Menggunting sesuai dengan } \\
\text { pola garis vertikal, } \\
\text { horizontal, lengkung, } \\
\text { Lingkaran }\end{array}$ & 50 & 65 & 115 & $57,5 \%$ & MB \\
\hline 4 & $\begin{array}{l}\text { Terampil menggunakan } \\
\text { jari tangan (mewarnai, } \\
\text { menggambar) dengan } \\
\text { gerakan naik, turun, } \\
\text { bersambung. }\end{array}$ & 53 & 73 & 126 & $63 \%$ & BSH \\
\hline & Rata-rata & & & & $61,5 \%$ & BSH \\
\hline
\end{tabular}

Sumber: lembar observasi anak siklus II pertemuan ke-1 dan ke-2

Pada siklus III presentase yang diperoleh mengalami peningkatan yang signifikan pada aspek memegang alat/benda dengan baik (antara ibu jari dan 2 jari) sebesar 27,5\%, aspek menempel gambar dengan tepat sebesar $31 \%$, aspek menggunting sesuai dengan pola garis vertikal, horizontal, lengkung, lingkaran sebesar 20\%, aspek terampil menggunakan jari tangan (mewarnai, menggambar) dengan gerakan naik, turun, bersambung sebesar $26 \%$. Jadi secara keseluruhan per aspek dari siklus I ke siklus II meningkat sebesar 23,5\% dan siklus II ke siklus III mengalami kenaikan sebesar 26,5\%. 
Berdasarkan data hasil penelitian tindakan kelas yang telah dilaksanakan menunjukkan hasil yang diharapkan, sesuai dengan tingkat keberhasilan anak. Berikut rekapitulasi hasil perkembangan kemampuan motorik halus anak dari siklus I, siklus II, dan siklus III. 


\section{Rekapitulasi hasil pengamatan kemampuan}

motorik halus melalui montase siklus I, siklus

\section{II, dan siklus III}

\begin{tabular}{|c|c|c|c|c|}
\hline \multirow{2}{*}{ No } & \multirow{2}{*}{ Aspek yang dinilai } & \multicolumn{3}{|c|}{ Siklus } \\
\hline & & I & II & III \\
\hline 1 & $\begin{array}{l}\text { Memegang alat/benda } \\
\text { dengan baik (antara ibu jari } \\
\text { dan } 2 \text { jari) }\end{array}$ & 32,5 & 59 & 86,5 \\
\hline 2 & $\begin{array}{l}\text { Menempel gambar dengan } \\
\text { tepat }\end{array}$ & 45 & 66,5 & 97,5 \\
\hline 3 & $\begin{array}{l}\text { Menggunting sesuai dengan } \\
\text { pola garis vertikal, } \\
\text { horizontal, lengkung, } \\
\text { lingkaran }\end{array}$ & 30,5 & 57,5 & 77,5 \\
\hline 4 & $\begin{array}{l}\text { Terampil menggunakan jari } \\
\text { tangan (mewarnai, } \\
\text { menggambar) dengan } \\
\text { gerakan naik, turun, } \\
\text { bersambung. }\end{array}$ & 43 & 63 & 89 \\
\hline & Jumlah & 151 & 246 & 350,5 \\
\hline & Rata-rata & $38 \%$ & $61,5 \%$ & $88 \%$ \\
\hline & Kerite ria & $\mathrm{BB}$ & BSH & BSB \\
\hline
\end{tabular}

Sumber:rekapitulasi lembar observasi anak siklus I, II, III

Dengan demikian penelitian dikatakan berhasil karena peningkatan keterampilan motorik halus anak pada siklus III ini memenuhi kriteria keberhasilan yang ditetapkan yaitu 70\% sesuai dengan kesepakatan guru kelas/kolabolator.

\section{SIMPULAN}

Berdasarkan hasil penelitian dan pembahasan penelitian tentang "Peningkatan Kemampuan Motorik Halus Anak Melalui Kegiatan Montase Usia 5-6 Tahun di TK. Barunawati 3 Samarinda Tahun Ajaran 2016/2017" yang telah dilaksanakan dalam siklus I, II, dan III. Hasil penelitian yang dilakukan menunjukkan perolehan jumlah nilai pada siklus I yaitu 151 perolehan nilai rata-rata yaitu $38 \%$ dengan kriteria belum berkembang. Pada siklus 
II yaitu $246,5 \%$ perolehan nilai rata-rata yaitu $62 \%$ dengan kriteria berkembang sesuai harapan. Pada siklus III yaitu 350,5\% nilai rata-rata yaitu $88 \%$ dengan kriteria berkembang sangat baik. Berdasarkan data tersebut di atas, maka peneliti menyimpulkan kegiatan montase dapat meningkatan kemampuan motorik halus anak usia 5-6 tahun di TK. Barunawati 3 samarinda.

\section{REFERENSI}

Hildayani Rini. (2007). Psikologi Perkembangan Anak Usia Dini. Jakarta:Universitas Terbuka.

J.W. Santrok (2007). Perkembangan Anak Edisi ke Sebelas Jilid 1. Jakarta: Penerbit Erlangga.

Muharrar Syakir, dan Verayanti Sri. (2013). Kolase, Montase, dan Mozaik.

Jakarta: Essensi Erlangga Group.

Rasyid Harun, Mansyur dan Suratno. (2009). Assesmen Pembelajaran di Sekolah.

Jakarta: Multi Pressindo.

Sanjaya Wina. (2009). Penelitian Tindakan Kelas. Jakarta: Prenadamedia Grop

Suharsaputra Uhar. (2012). Metode Penelitian Kuantitatif, kualitatif, dan Tindakan. Bandung: PT. Refika Aditama.

Sujiono Bambang. (2008). Medote Pengembangan Fisik. Jakarta: Universitas Terbuka

Sumantri. (2005). Model Pengembangan Keterampilan Motorik Anak Usia Dini.

Jakarta: Departmen Pendidikan Nasional.

Samsudin. (2008). Pembelajaran Motorik di Taman Kanak-kanak. Jakarta; Litera.

Wahyudin Uyu dan Agustin Mubiar. (2011). Penilaian Perkembangan Anak Usia Dini. Bandung: PT. Refika Aditama. 